\title{
MEMÓRIA E ESPIRITUALIDADES FEMININAS: UM OLHAR DA HISTÓRIA DAS RELIGIÕES* ${ }^{*}$
}

\author{
Lyndon de Araújo Santos \\ UFMA
}

\section{Introdução}

Traço fundamental em todas as religiões, a oralidade e a memória se constituíram como meios de preservação e de transmissão de narrativas que estruturavam as próprias sociedades organizadas em torno do sagrado. Desde o mundo antigo, as narrativas míticas foram os conteúdos de sentido portadores de uma dada racionalidade que, por meio da linguagem e das representações rituais, compuseram parte das memórias socialmente estabelecidas pelos grupos sociais. Junto aos escritos e aos textos revelados fundantes das suas tradições, a oralidade e a memória percorreram os tempos formando sentidos ora complementares, ora concorrentes aos escritos sagrados, aos rituais, às tradições e às experiências religiosas. Daí a relação entre essas memórias e as espiritualidades, que tiveram, invariavelmente, a presença das mulheres como agentes e sujeitos responsáveis pela preservação, transmissão e ressignificação, a partir dos seus lugares e dos seus papéis sociais desempenhados em cada sociedade.

O intento deste capítulo é, principalmente, apresentar as espiritualidades femininas dentro do universo religioso protestante, convergindo para exemplos de mulheres que expressaram com relevância um tipo de espiritualidade nesse segmento religioso, embora delimitadas às condições que lhes eram impostas por uma sociedade patriarcal. Contudo, uma pequena discussão sobre a relação entre o feminino e a espiritualidade em algumas das principais tradições religiosas precede a apresentação das mulheres protestantes como representantes de uma espiritualidade vivenciada em diferentes tempos e contextos.

Discorro inicialmente sobre esse feminino na história em sua direta relação com o religioso, o sagrado e a espiritualidade, problematizando a partir da história das religiões, essa presença fundamental nas experiências e nas vivên-

\footnotetext{
*DOI - 10.29388/978-65-86678-62-8-0-f.105-123

1 Texto originalmente apresentado na mesa redonda "Feminismo, Religião e Espiritualidade", como parte da programação do VII Encontro Maranhense sobre Educação, Mulheres e Relações de Gênero no Cotidiano Escolar (EMEMCE) e do VII Simpósio Maranhense de Pesquisadoras(es) sobre Mulher, Relações de Gênero e Educação (SIMPERGEN). O evento ocorreu nos dias 10 a 13 de setembro de 2019, no Centro Pedagógico Paulo Freire, UFMA. O presente capítulo foi ampliado e adaptado para esta publicação.
} 
cias religiosas. Num segundo momento, discorrerei sobre mulheres protestantes que, por meio das suas espiritualidades e experiências com o sagrado, atuaram de algum modo como agentes de mudanças nas relações de gênero, mesmo que não expusessem política e ideologicamente uma linguagem e uma postura alinhadas ao movimento feminista.

A temática destaca a importância e a necessidade de se desconstruir uma leitura unilateralmente negativizada da religião, a partir das espiritualidades femininas presentes nas diversas tradições religiosas. As religiões mais institucionalizadas se tornaram um espaço de poder e de controle masculino, excluindo as mulheres dos seus serviços, rituais, do ensino e do sacerdócio.

No entanto, há que se rever a leitura que reifica a absoluta passividade destas. Juan José Tamayo nos diz sobre o despertar religioso da espiritualidade feminista que questiona "as formas clássicas de representação do divino e as concepções morais do eterno feminino que exigiam às mulheres uma vida religiosa de renúncia, resignação, silêncio, evasão, inimizade com a vida, desprezo pelo próprio corpo e negação do prazer" (TAMAYO, 2009, p. 55). Tal espiritualidade é vivida a partir da sua própria subjetividade que tenta ser subjugada pelas mediações clericais e patriarcais ou hierárquico- institucionais, não aceitando as divisões tradicionais entre sagrado e profano, espiritual e material, natural e sobrenatural. Os espaços e as fronteiras onde essa espiritualidade se constrói seriam os mundos do trabalho, da política, da comunicação, da rua, no agora e no cotidiano. "Sua presença no mundo se orienta a transmitir o dinamismo libertador do E(e)spírito" (TAMAYO, 2009, p. 55).

Respectivamente, entendemos o feminino como representação e como construção social, e o feminismo como movimento político e social de defesa dos direitos, da dignidade e da igualdade de gênero, engendrado desde fins do século XIX e que avançou até aos nossos dias, configurando-se, talvez, como sendo o principal movimento revolucionário ocorrido no século XX.

[...] de uma maneira geral, poderia se definir o feminismo como o movimento social que reivindica a melhoria das condições de vida das mulheres, e, para isso, almeja eliminar as desvantagens em relação ao status alcançado pelos homens ao longo da história. Ou talvez seria melhor dizer "feminismos", uma vez que a pluralidade de abordagens é uma das características que esse trabalho busca respeitar (LUCENA, 2012; MIGUEL e BIROLI, 2014, Apud ANTONINO, 2018).

Essa distinção se coloca necessária ante o discurso atual que contrapõe seus significados por parte de setores conservadores, incluindo mulheres a 
exemplo da atual ministra Damares, ao identificarem o feminismo como ameaçador de uma condição social fixa, imutável e essencialista do que seja a condição feminina.

Porquanto, a luta pela igualdade de gênero, também teve no espaço religioso expressões e manifestações que foram determinantes para as suas conquistas, sendo a espiritualidade uma dimensão que, histórica e socialmente, contribuiu, mediou, retrocedeu, mas que também avançou nestas conquistas.

\section{Feminino e Espiritualidade}

A relação entre a espiritualidade e o feminino na esfera religiosa foi, e tem sido, um fenômeno inseparável na história humana. O estudo das espiritualidades nos oferece, nesse momento, uma possibilidade de se pensar a relação entre formulações dogmáticas ou cosmogônicas e as relações sociais concretas.

Por espiritualidade entendemos toda e qualquer expressão humana dirigida ao referente sagrado ou que toma este referente como fonte de inspiração, de prática, de ação e de comunhão com o transcendente. André Vauchez a define "como unidade dinâmica do conteúdo de uma fé e da maneira pela qual esta é vivida por homens [e por mulheres] determinados" (VAUCHEZ, 1995, p. 8). A espiritualidade se confunde com a própria religiosidade que atua tanto no espaço oficial do religioso como para além das suas fronteiras institucionais desse religioso. O problema da espiritualidade está no fato dela ser potencialmente transgressora dos limites que o religioso define para a sua expressão e para a sua manifestação. Pois, ela está ligada diretamente à dinâmica social e cultural que impõe, tanto ao sujeito religioso como à instituição religiosa, a necessidade de adaptação e de ajustes para sua reprodução e sobrevivência. Se, por um lado, a espiritualidade tende a romper com os limites e as fronteiras do religioso estabelecido, ela pode atuar como reprodutora e legitimadora deste mesmo modelo instituído.

Como dimensão histórica e cultural, desde as mais antigas civilizações ou desde as primeiras populações arcaicas, o feminino esteve ligado à espiritualidade e às expressões de religiosidade. No entanto, esta relação não esteve dissociada aos papéis sociais que as mulheres exerceram nestas sociedades, originalmente guerreiras e agrícolas. Mircea Eliade nos diz que

[...] a solidariedade reconhecida entre a fecundidade da gleba e a da mulher constitui um dos traços marcantes das sociedades agrícolas. Durante muito tempo os gregos e os romanos assimilaram gleba e matriz, ato gerador e trabalho agrícola. Encontramos essa assimilação, por outro lado, 
em muitas civilizações e ela deu origem a grande número de crenças e ritos (ELIADE, 1998, p. 207).

Deusas e entidades femininas estiveram ligadas à fertilidade da terra e à garantia da reprodução humana do grupo social ao qual eram ligadas. Nas religiosidades das antigas civilizações mesopotâmicas, divindades femininas eram veneradas a partir da direta ligação aos ciclos da natureza e do plantio, a exemplo das imagens dos baalins e astarotes na região do oriente médio.

Sacerdotisas, feiticeiras, bruxas, benzedeiras, madres, freiras, beatas, santas, profetizas pentecostais e pastoras compõem, no âmbito do cristianismo, os lugares de referência no campo institucional e popular. O domínio e o conhecimento de rezas e orações, juntamente com raízes, unguentos, chás, ervas, plantas e outros meios medicinais permitiram às mulheres espaços e condições de poder e de controle, mesmo sob a configuração de uma sociedade patriarcal, na antiguidade e no medievo.

O judaísmo mesmo sob uma ordem patriarcal conta com tradições que reservaram às mulheres papéis fundamentais na criação dos filhos por meio de uma primeira educação e, nas narrativas vétero-testamentárias, tem-se a incidência de profetizas, líderes militares, rainhas e mulheres comuns que foram determinantes na história do povo de Israel. Nas religiosidades afro-brasileiras, a condição feminina se impõe nas representações tanto da presença das mães de santo como lideranças de terreiros, guardiães das tradições e dos segredos, pelo domínio das práticas e dos rituais, como nas entidades femininas compreendidas como seres de força, de vontade, de gostos e que intervém no cotidiano dos adeptos.

No islamismo, em sua história de formação religiosa e cultural, figuras como Kadja esposa de Maomé, figuram como centrais nas narrativas das origens. O Alcorão remete as mulheres à condição de subalternidade com uma condição complementar, embora com tarefas e papéis sociais fundamentais na estruturação das sociedades islâmicas. Assim, por um lado, as mulheres, de acordo com o grau de conservadorismo nas interpretações alcorânicas e dos modelos de sociedades patriarcais, ocupa um espaço secundário na ordenação religiosa oficial islâmica, mas exerce no cotidiano funções e papéis de relevância e de autodeterminação.

No hinduísmo, entre as cerca de 33 milhões de divindades. Shakti, a grande mãe, na corrente do Shaktismo é tomada como um ser supremo tal como Brahma, considerada a força cósmica primordial e a energia das divinda- 
des, e se manifesta pela forma das deusas Saraswati, Parvati e Lakshmi, que formam uma outra trindade sagrada, chama Tridevi. ${ }^{2}$

O saktismo, forma esotérica e extrema do culto, vê na Deusa o momento eterno de autoconsciência e de liberdade do Absoluto, o aspecto "dinâmico" em oposição ao impassível fulgurar da consciência irrefletida de Siva, cadáver branco com quem a deusa, nua e negra, é empenhada a copular. Os Sakatantra exaltam a sakti no seu papel de Senhora suprema no vértice do panteão indiano, objeto de culto nas suas várias manifestações, das quais se destaca Kali e Tripurasundari (RAVERI, 2005, p. 80).

As lógicas destas cosmogonias pressupõem o lugar e a condição do feminino na ordem social com seus arranjos e configurações. Não somente no âmbito das explicações doutrinárias, mas nas próprias relações sociais, o feminino se impõe com suas estratégias, práticas e discursos, nas múltiplas tensões, conflitos, conciliações e opressões por que passam as mulheres no cotidiano.

Assim, a religião expressa as ambiguidades e as contradições das relações de gênero quando as divindades femininas ocupam um lugar de proeminência nas formulações doutrinárias com seus poderes e papéis definidos na ordenação mágica e sagrada das ações no mundo, mas nas relações sociais e institucionais são alvos de opressão e exclusão por parte do controle masculino. A história das religiões há que dialogar com outros saberes que operam releituras desde as fontes que são fundantes das tradições religiosas:

No seio das religiões tradicionais, textos sagrados começaram a tornar-se objeto de uma releitura crítica. A ministra protestante Brackenbury Crook (1964), por exemplo, ofereceu uma reanálise feminista da teologia e da Bíblia, enquanto a teóloga católica Elisabeth Schüssler Fiorenza (1983), uma das fundadoras do Journal of Feminist Studies in Religion, usou uma perspectiva feminista com um cunho político e hermenêutico em sua releitura de textos sagrados. Feminismo também é confrontado com a religião (Giorgi, 2016). Feminismos (por exemplo, o feminismo negro nos EUA) combinava ativismo político com forte religiosidade dentro de religiões tradi-

\footnotetext{
${ }^{2}$ Lakshmi personifica o amor como esposa de Vishnu que é o sustentador do universo. Lakshmi também personifica a beleza, a fartura, a generosidade e a riqueza da fortuna, como símbolo da potência feminina e reconhecida por sua juventude e formosura eternas. Muito popular na Índia, é adorada principalmente pelos que estão em dificuldades financeiras. Saraswati, mulher de Brahma e a mão dos Vedas, é a deusa do conhecimento, da arte, da música e da sabedoria. Parvati é a deusa da fertilidade, da beleza, do amor e do casamento, esposa de Shiva e encarnação de Shakti. In: <https://www.hipercultura.com/hinduismo-conheca-os-principais-deuses-indianos/> e $<\underline{\text { https://fenixdefogo.wordpress.com/2013/08/10/hinduismo-mitologia-hindu-deusas-hin- }}$ dus-lakshmi-sarasvati-saraswati-e-sati-parvati-durga-e-kali/> Acesso em: 6 set. 2019.
} 
cionais (Lorde, 1984; hooks, 1990). A este respeito, deve-se referir o desenvolvimento extremamente inspirador da teologia da mulher, com seu foco sobre a adoção da feminilidade preta e sua atenção para o papel da religião na experiência de mulheres negras (Walker, 1983) (ANTONINO, 2018).

Uma questão a ser discutida pela história das religiões está na relação entre o lugar do feminino nas cosmogonias, nas narrativas e nos dogmas, e as formas concretas das vivências das mulheres nas relações sociais, nos quadros do patriarcalismo como visão de mundo estruturante das sociedades. A teóloga Ana Maria Bidegain afirma que

[...] a incorporação da categoria de gênero, cruzada com as de classe social e etnia, não só é útil para a elaboração da história das religiões, é também uma chave essencial para a compreensão da história invisível das mulheres nas religiões e suas relações com todas as formas de estruturação do poder (BIDEGAIN, 1996, p. 28).

\section{Protestantes (quase) Feministas}

Já na Reforma Protestante, pela força da doutrina do sacerdócio universal dos santos e de outros fatores, mulheres atuaram na forma de emancipação do poder clerical no caso de freiras e de um evidente protagonismo, como no caso da esposa de Martinho Lutero, Catharina Von Bora, dentre outras. Claudete B. Ulrich registra a invisibilização das mulheres nas narrativas históricas da reforma:

A história que chegou até nós foi a dos homens heróis e de seus grandes feitos. Nomes como Martinho Lutero, João Calvino, entre outros, são conhecidos. No entanto, nomes como Argula Stauff von Grumbach, Elisabeth von Calenberg, Elisabeth Schütz Zell ou Katharina von Bora são praticamente desconhecidos. O historiador Martin Jung, no seu artigo "Nenhuma reforma sem o apoio das mulheres", na página da Igreja em Württenberg, afirma que a Reforma não teria acontecido sem a participação efetiva das mulheres (JUNG, s.a,, s. p.). (ULRICH, 2016, p. 73).

Embora não engajadas no movimento feminista como tal, não poucas mulheres protestantes atuaram em seus espaços religiosos de um modo a firmar um lugar de fala e de poder. Favorecidas direta ou indiretamente pelo avanço das lutas pelos direitos das mulheres, construíram condições para que, no interi- 
or das instituições religiosas, conquistassem vozes, visibilidade e fossem protagonistas de mudanças da própria condição da mulher, por meio da espiritualidade.

Nos idos de 1830, mulheres britânicas protagonizaram o maior movimento da sociedade civil contra a escravidão levantando cerca de 180 mil assinaturas encaminhadas ao parlamento pelo fim do regime escravista.

\begin{abstract}
Ainda mais significativa foi a transposição dos limites de gênero, maciçamente vencidos na década de 1830. Como pioneiras das petições em massa modernas, as mulheres britânicas emergiram, por si mesmas, como organizadoras e apoiadoras independentes. Em 1833, sua maior petição foi apresentada com mais de 180.000 nomes, tornando-se o documento abolicionista entregue ao Parlamento mais amplamente divulgado em meio século de mobilizações desse gênero. Até o final da década de 1830, as mulheres tinham provavelmente ultrapassado o número de homens signatários de petições enviadas ao Parlamento e endereçadas ao monarca (DRESCHER, 2015, p. 35).
\end{abstract}

Nos Estados Unidos escravista, grupos de mulheres de igrejas independentes e batistas moveram campanhas antiescravistas, mobilizando ações filantrópicas e políticas, editando panfletos e mobilizando a sociedade civil pelo fim do regime escravista. Partiam do entendimento outro na interpretação das escrituras relendo-as a partir de suas óticas e até editando uma versão do que seria uma bíblia da mulher, precursoras da chamada teologia feminista contemporânea.

Já no século XIX, surge a primeira elaboração feminista de interpretação do texto bíblico, feita por mulheres especialistas na área. Elisabeth Cady Stanton publica, entre 1895 e 1898, nos Estados Unidos, um projeto coletivo de revisão e de reinterpretação da Bíblia. Esse trabalho, publicado sob o título The Woman's Bible é considerado o ponto de partida de um longo e fragmentado processo que levará, no final dos anos 60 do século $\mathrm{XX}$, à constituição de uma Teologia Feminista, em concomitância com o surgimento da Teologia da Libertação (ROSADO, 2001, p. 81).

Na Europa, um movimento destacado foi

O Protestant Mouvement Jeunes Femmes [que] surgiu em 1946, quando algumas participantes afirmaram que gostariam de criar uma estrutura na qual as mulheres cristãs pudessem buscar a realização espiritual, dar apoio umas às outras e se esforçar para lidar com problemas específicos relacio- 
nados à sua situação. Uma questão importante, para aquele tempo, era a possibilidade de mulheres serem pastoras, a discussão veio à tona e em 1949, Elisabeth Schmidt liderou a primeira congregação. Outras mulheres também foram notáveis por defender os valores intrínsecos de sua fé protestante e ao mesmo tempo defender os ideais feministas: Jeanne Lebrun, (1903-1996); Suzette Duflo, (1910-1983); Francine Dumas (1917-1988) e Christine Rigal. Seus principais temas de defesa foram: planejamento familiar, o desenvolvimento harmonioso do casal, o direito das mulheres para com o trabalho fora de casa, as mulheres assumindo responsabilidades na Igreja (CHAPERON, 2000). (ANTONINO, 2018).

No Brasil, mulheres protestantes foram agentes de mudanças em distintas situações e contextos, a exemplo das missionárias educadoras (metodistas e presbiterianas), que além de ensinar, dirigiram escolas e trouxeram métodos pedagógicos vanguardistas para um Brasil ainda imperial de precária política educacional voltada para as populações pobres. Exerceram lideranças em instituições pedagógicas e eclesiásticas angariando poder e prestígio, quando a adesão religiosa ao protestantismo significava dentre outros fatores uma possibilidade de ascensão social. Embora proibidas de exercerem o ministério pastoral criaram seus espaços como educadoras, professoras, líderes nas comunidades locais e atuantes no assistencialismo, uma experiência compartilhada nas diferentes denominações estabelecidas ${ }^{3}$.

Outras mulheres protestantes foram agentes de mudanças em outras esferas que não somente o educacional, a partir da experiência religiosa ou da espiritualidade.

\section{Jacobina Mentz Maurer}

A religiosa de origem protestante luterana, Jacobina, liderou um levante de lavradores e de pequenos agricultores no Rio Grande do Sul, nos fins do oitocentos, contra o avanço da grande propriedade e da modernização, que ameaçavam as terras e as propriedades dos colonos. Jacobina Mentz, junto com seu esposo, por meio de revelações, mensagens apocalípticas e de manifestações miraculosas, alcançou a crença de que era enviada por Deus por parte daquela população e reuniu um grupo de resistência que chegou ao conflito armado e ao massacre do movimento.

O movimento, chamado os Mucker, pode ser considerado como um dos messianismos milenaristas de fins do século XIX e início do XX, ao lado de

${ }^{3}$ Ver SILVA, 2015, pp. $161-190$. 
Contestado, Caldeirão e Canudos, as que teve influência direta do pietismo alemão.

A primeira colônia alemã fundada no Rio Grande do Sul, em São Leopoldo, em 1824, foi palco de um movimento denominado Mucker, que se configurou a partir de 1868. Quando, colonos se reuniram em torno da liderança do casal Jacobina Mentz Maurer e João Jorge Maurer, na região do Ferrabraz, hoje localizado no município de Sapiranga. O episódio envolveu localidades que tiveram São Leopoldo como municípiomãe e que geograficamente, com base na hidrografia, ocupam a região do Vale do Rio dos Sinos. [...] A protagonista dos fatos ocorridos no Morro Ferrabraz, em Sapiranga, no Rio Grande do Sul, é Jacobina Mentz, nascida em junho de 1842, em Novo Hamburgo 3, filha de colonos alemães que chegaram ao Brasil nos primeiros anos da imigração alemã. Sua família tivera problemas de ordem religiosa na Alemanha, pois, adepta do grupo pietista da Igreja Luterana, não se conformava com as novas orientações da instituição, quanto à linha adotada, e acusava-a de desviarse dos ensinamentos bíblicos. Libório Mentz, avô de Jacobina, coordenou o grupo descontente, que se mudou para o povoado de Tambach, onde fundaram nova igreja e não permitiam que seus filhos frequentassem a escola. Nesse período, o patriarca e a família emigraram para o Brasil. Em Novo Hamburgo, ele construiu uma igreja e organizou um coral, participando, assim, ativamente das atividades religiosas da comunidade, sem envolver- se em novos conflitos (WEBER, 2012, p. 136,137).

\section{Frida Maria Strandberg Vingren}

Esposa de um dos missionários fundadores do assembleísmo pentecostal, o sueco Gunnar Vingren, Frida chegou ao Brasil em 14 de julho de 1917, projetando-se como pregadora, editora, educadora, nas primeiras décadas da igreja Assembleia de Deus no Brasil, a partir de Belém e do Rio de Janeiro (ALENCAR, 2013).

Sua atuação causou desconfortos nas lideranças masculinas da nascente igreja Assembleia de Deus, tanto de brasileiros como de suecos, sobretudo com o pastor Samuel Niström.

No início, Frida restringe seu trabalho aos serviços sociais da igreja, tradicionalmente entregues às mulheres. Cuidar dos filhos, zelar pelos órfãos, visitar os idosos e os doentes. A jovem ia com frequência aos centros afastados que isolavam pacientes com hanseníase do restante da po- 
pulação - os chamados leprosários, que surgiram no Brasil naquela época ,$-[\ldots]$. Com o tempo, a missionária assume cada vez mais as atribuições de Gunnar em Belém. Talentosa, ela começa a traduzir os hinos da igreja sueca para o português. Canta, toca e começa a pregar (MOTA, 2018).

Criou um jornal chamado "Som Alegre" que expressava a defesa do ministério feminino das pastoras, pregava em praça pública e dirigia escola dominicais nas prisões no Rio de Janeiro.

Em 12 de julho de 1930, na primeira convenção eclesiástica realizada pela igreja, convocada por causa de Frida, foi decidido o enquadramento das mulheres e o cerceamento de serem pregadoras e de exercerem certas funções de liderança restritas aos homens. ${ }^{4}$ Vencida pela decisão, Frida intensificou sua oposição à convenção, conclamando as mulheres a desafiarem tais decisões.

Desde então, com tensões com a liderança de Samuel Nistrom e alvo de suspeitas em torno de sua conduta moral, Frida enfrentou oposições à sua performance e projeção. Frida teve que retornar para a Suécia onde veio a falecer seu esposo.

A situação fica insuportável no Brasil e, em de 1932, o casal, que na época tinha seis filhos, decide retornar à Suécia. Antes de partir, contudo, eles perdem a filha mais nova - e Gunnar morre pouco tempo depois de chegar à Europa. [...]. Frida quer retomar a vida de missionária, mas a liderança da igreja no Brasil não aprova seu retorno. Na Suécia, suas aspirações também são tolhidas por Lewi Pethrus, um dos maiores líderes da igreja pentecostal no país. Em 1964, Pethrus fundaria o partido democrata-cristão sueco - o Kristdemokraterna $(\mathrm{KD})$-, de centro-direita. Diante dos reiterados pedidos de Frida, o líder afirma que seu trabalho no Brasil havia prejudicado a missão e dá-lhe um não definitivo. Ela levanta então recursos por conta própria e decide ir para Portugal (MOTA, 2018).

Ao fazer a tentativa de voltar para o Brasil foi aprisionada na estação, tida como louca e internada num hospício onde veio a falecer nos braços da filha aos 49 anos e com 23 quilos, em 30 de setembro de 1940. No entanto, o legado de Frida de algum modo permaneceu no protagonismo feminino no assembleísmo brasileiro, por meio dos chamados círculos de oração.

\footnotetext{
4 “A situação escalou depois de um suposto caso de adultério de Frida com um brasileiro. Apesar de não haver uma confirmação documental do romance que a missionária teve com o rapaz, bem mais novo que ela, os indícios levam a crer que isso de fato aconteceu". Disponível em: $<$ https://www.bbc.com/portuguese/geral-44731827>. Acesso em: 10 set. 2019.
} 


\section{Eva Yarwood Mills (1903-1987)}

Foi uma inglesa que viveu e trabalhou no Norte e Nordeste do Brasil durante os anos de 1928 a 1959, como missionária e professora no contexto de difusão do protestantismo (SANTOS, 2006). Eva Mills registrou esse tempo no Brasil em três livros autobiográficos: o "8:28” (1976), "Em Lugar do Espinheiro" (1982) e "Stories from Parakeet Country" (1986).

As exigências para uma mulher no início do século XX a encaminharam à normatividade de um padrão que Eva Mills assumiu para si: trabalhadora, mãe, educadora e cuidadora, ao mesmo tempo que submissa e abnegada, cujo trabalho não poderia de forma alguma ofuscar o trabalho do marido, privando-a, por conta disso, do falar em público nos ambientes religiosos. Contudo, sua ação burlou as normas. A prática da docência, considerada uma de suas muitas funções se mostrou subversiva, ainda que tantas vezes impulsionada pelas intempéries da vida, levando-a a sair da sombra e a protagonizar uma vida que era sua. Entendo que a última etapa desta subversão foi justamente o ato de desinvisibilizar-se através de seu projeto autobiográfico, pela organização de sua memória e da legitimação de seu próprio lugar de pertença na História (VERAS, 2017, p. 182).

No Brasil, Eva Mills assumiu o campo educacional como seu lugar de ação, possibilitando um olhar privilegiado para as vivências e práticas gestadas em escolas no Norte do país. Escolas que, apesar de pequenas e distantes dos grandes centros urbanos, são capazes de explicitar a organicidade de culturas escolares operadas por missionários protestantes no Brasil e de evidenciar a ação de sujeitos a partir da mobilização de pequenos grupos na organização de suas escolas, conforme suas necessidades.

\section{Sarah Poulthon Kalley}

Sarah Kalley foi uma missionária inglesa de origem congregacionalista que reuniu seus talentos como tradutora, musicista, educadora, pintora, pastora e escritora, forjando um perfil de autonomia feminina em sua atuação no Brasil (1855 a 1876) e na Inglaterra (1876 a 1907). Sua contribuição foi decisiva para a configuração do protestantismo no Brasil até aos nossos dias (CARDOSO, 2005).

Como musicista traduziu e compôs cânticos religiosos de tradição reformada, organizando a coletânea que se tornou matriz da hinologia brasileira 
evangélica, os "Salmos \& Hinos". Como educadora, criou uma escola diária para crianças pobres filhas dos membros de sua igreja no Rio de Janeiro, inserindo matérias que não faziam parte do ensino formal da época como geografia, história natural, química, higiene etc. Embora nunca tenha se definido como tal, como pastora cuidou de pessoas, dirigiu reuniões, organizou as mulheres da comunidade, pregou e ensinou ao lado do esposo também pastor. Pintou quadros com um estilo simples e sóbrio, de cenários do Rio de Janeiro e de sua casa em Petrópolis, além de ilustrar com desenhos os livros que escreveu. Escreveu sermões para o esposo, administrou recursos e as vidas dos missionários da igreja, alimentou uma rede de contatos sociais importantes para o universo da época.

Uma de suas mais significativas produções foi um pequeno livro editado no Brasil que teve ampla circulação em Portugal, Ilha da Madeira, Trinidad \& Tobago e Illinóis, EUA (AFONSO, OLIVEIRA, STAMATTO \& SILVA, 2012). Inicialmente direcionado às mulheres da sua igreja, o livro teve como título "A Alegria da Casa", obra escrita em 1866 e que seria adotada como livro didático para o ensino público nos tempos do império até a década inicial da república. Suas páginas retratam a visão de mundo de uma inglesa filha de industriais de Liverpool, com seus valores protestantes puritanos e com a experiência de vida no Brasil, reproduzindo um manual de civilidade, com noções de higiene, de administração da casa ou de economia doméstica e a preparação das moças para o casamento (LIMA, 2017).

No artigo, "Educação e cultura protestante na transição do século XIX: circulação de impressos e diálogos luso-brasileiros", seus autores fizeram o seguinte comentário sobre a autora:

Faz-se necessário problematizar a vontade de saber e o desejo dessa educadora em fazer as letras desenharem no papel uma história possível para o gênero feminino, uma gramática inspirada em vários campos do conhecimento, dentre os quais o saber médico, o pedagógico, o sanitário, o arquitetônico, o familiar. São fios tecidos na intersecção de práticas religiosas protestantes, médicas e familiares, com circulação e apropriação nas duas margens do Atlântico. Na perspectiva protestante, abrem-se possibilidades ao elemento feminino - seja numa participação efetiva, como no caso da publicação/distribuição/circulação do livro A Alegria da Casa, seja como redatoras, correspondentes, educadoras e gestoras das escolas protestantes (AFONSO, OLIVEIRA, STAMATTO \& SILVA, 2012, p. 601). 
O artigo destaca "A Alegria da Casa" como sendo um rico texto esculpido "pelo punho feminino, uma função não muito bem vista naquele contexto", onde imprimiu traços do seu tempo e lugar.

Representou o homem ao escrever sobre a mulher. Lembrou dos vivos sem esquecer dos mortos -, das bactérias, dos miasmas, da doença, do gênero feminino, da educação doméstica, das noções de educação e de pedagogia fincadas na Modernidade e nos ideais Iluministas, [...]. A Alegria da Casa é um livro-texto que, assim como a pedra das casas e das calçadas, o tecido das lojas e dos armazéns, o receituário médico, as cartilhas de alfabetização e de leitura, forneceu suporte no qual a escritora inscreveu o cotidiano das mulheres do seu tempo em suas relações com os homens, com os filhos, com a sociedade e com a leitura (AFONSO, OLIVEIRA, STAMATTO \& SILVA, 2012, p. 601).

O texto retrata o cotidiano das mulheres da época nas relações com os homens, os filhos, a sociedade e a leitura. São regras do bom viver, do fino trato, do modo de se vestir e de se comportar nos papéis de mãe, de esposa e de dona de casa, responsável por normas médicas, ordens familiares e de ritos cotidianos. Contemporâneo ao discurso higientista, discorreu sobre as superstições curativas, o charlatanismo e receituários contra os males que atingiam a população pobre e rica de um país tropical.

Pena-estilete que cortou as grossas fronteiras de gênero, que delimitavam a escrita feminina a um lugar marginal, inferior, secundário; que circunscrevia os manuais de bom-tom para os grandes nomes. Sarah corta, recorta, tricota a própria geografia feminina e desenha novas possibilidades para a mulher, elaborando discursivamente novos valores culturais, (re)definindo os papéis femininos, discutindo os espaços, tentando desconstruir paradigmas existentes na sociedade brasileira que impunham à mulher um papel fixo, imutável, rígido. Pena-pincel que, de uma maneira poética, pintou e historicizou o corpo feminino, inscreveu-o na história, nos espaços, nos espaços da história do século XIX. Com arte, foi sensível à história da docilidade, do carinho, da esperança, do recato de mulheres que amam seus maridos, seus filhos, sua casa. Pincel que deu colorido às casas preto-e-branco, cheia dos projetos e sonhos que cercavam as mulheres. É necessário ter estética para narrar nas páginas da história o sentido e alegria que têm a repetição diária dos afazeres domésticos. É preciso poesia para enxergar na água e no sabão a alegria da casa (AFONSO, OLIVEIRA, STAMATTO \& SILVA, 2012, p. 601). 
Cada cômodo da casa deveria ser devidamente asseado desde uma concepção religiosa de pureza ligada à noção de higiene, lembrando a abordagem da antropóloga Margareth Mead. A ventilação, a iluminação, a limpeza, o asseio e a decoração visavam a saúde e bem-estar da família, a imagem de uma casa bem ordenada, sob a governança da mulher.

[...] lavada uma vez por semana, espanando-se primeiramente as paredes e o teto, tornando-a ' $[. .$.$] sempre agradável e saudável', pois consis-$ tia em um local de vivências: $\mathrm{Na}$ sala de visita, como na sala de jantar, como em todos os outros lugares e aposentos de uma casa bem governada, a coisa principal é o asseio, pois isto não confere somente um ar de agradável conforto à morada, [...] como uma boa ideia do morador. (KALLEY, 2005, p. 78, 81).

[...] Triste coisa é que na maior parte das moradas não se achem quartos de dormir, propriamente ditos, mas somente alcovas sepultadas no interior das casas, sem janelas, e em geral tão estreitas, e de tão mesquinhas dimensões que, uma vez cerradas as portas, mal podem os desgraçados habitantes tomar fôlego. (KALLEY, 2005, p. 75). (Apud AFONSO, OLIVEIRA, STAMATTO \& SILVA, 2012, p. 601).

A ideia de Sarah é a de uma direta intervenção e governo feminino nesse universo cotidiano familiar, num contexto de extrema precarização das condições de moradia. A limpeza deveria se contrapor à arquitetura ainda colonial das casas e à sua estética simples, independente da classe social. Discorre sobre o modo como se deve limpar cada cômodo, cada mobília, com o uso do pano, do espanador, da água e do sabão, observando uma regularidade semanal e diária, um conjunto de tarefas não exclusivo da mulher.

Conforme discute o artigo, "na narrativa kalleyana há uma geografia do espaço doméstico" e, ainda, "podemos inferir, assim, que a casa possuía ordenamentos como uma escola, com um currículo e um modus operandi", sendo também "o exemplo o grande diferencial dessa proposta" (AFONSO, OLIVEIRA, STAMATTO \& SILVA, 2012, p. 610).

É preciso ressaltar, no entanto, a dimensão que o livro propõe para esse cuidado com o lar. Ser uma boa administradora deste mantê-lo asseado, dedicar-se com amor era mais do que simplesmente executar tarefas banais e rotineiras: estava nas mãos da mulher a responsabilidade da saúde e felicidade dos membros da casa. Ou seja, traz uma perspectiva de importância para o elemento feminino no ritmo do cotidiano, uma dinâmica de administração para o espaço privado. Podemos afirmar, assim, que o livro A Alegria da Casa certamente teve uma intensa utilização no final 
do século XIX, não apenas na Igreja Evangélica Fluminense, lócus da atuação dos Kalley, mas também no cotidiano escolar de alunos e alunas, professores e professoras, como um manual de boas maneiras, um código de bom-tom para quem realizava uma contínua leitura de seus capítulos (AFONSO, OLIVEIRA, STAMATTO \& SILVA, 2012, p. 601).

O livro serviu como meio de transmissão de valores normativos de civilização, de noções de higiene pessoal e coletiva, foi um meio de divulgação da educação sanitária, da limpeza do corpo e da casa, tendo grande circulação e reapropriações por parte dos leitores e das leitoras, conforme Roger Chartier. Contudo, esse conjunto de concepções estava ligado a uma visão de mundo religiosa e a uma espiritualidade tecidas desde o olhar feminino protestante que dava à mulher um papel de protagonismo nos espaços que, por um lado, reproduziam a própria ordem patriarcal, mas, por outro, reforçaram os papéis de autonomia das mulheres. Cardoso afirma que Sarah propõe "uma atitude feminina pautada na reflexão e na racionalidade. [...] Não aceita o estereótipo da donade-casa frágil e intelectualmente deficiente, incapaz de tomar decisões racionais" (CARDOSO, 2005, p. 17).

\section{Os Círculos de Oração}

O uso da memória no movimento pentecostal latino-americano e brasileiro foi de fundamental importância para o seu desenvolvimento e dinâmica social. A história desse pentecostalismo não se deu sem a ingerência definitiva e determinante das mulheres em vários níveis e processos, dentro e fora das estruturas eclesiásticas que se formaram.

Surgido e forjado como uma religiosidade da fala, baseada no falar em línguas, onde o texto escrito e a racionalidade formal eram secundários diante da força do discurso e da experiência, o pentecostalismo teve nas mulheres um crucial suporte e estruturação para o seu avanço e enraizamento, embora muitas vezes esquecidas e marginalizadas pela produção acadêmica e pelos registros históricos oficiais das denominações.

$\mathrm{Na}$ própria origem do pentecostalismo nos EUA evidencia-se mais as figuras masculinas do que as femininas, assim como se deu no Brasil. Emblematicamente, o pentecostalismo assembleiano entrou no Maranhão no ano de 1921 por meio de um missionário, Clímaco Bueno Asa, mas foi uma mulher a primeira a falar em línguas, o sinal mais claro do batismo com o Espírito Santo que caracteriza esse movimento (SANTOS, 2006, p. 53-56). Não há nenhuma igreja pentecostal assembleiana e de outras denominações de recorte pentecos- 
tal onde a ação feminina não tenha sido fundamental na sua origem e na sua formação.

Tomando-se a Igreja Assembleia de Deus como padrão e modelo desse pentecostalismo, as mulheres foram agentes anônimas e, ao mesmo tempo, centrais na transmissão de uma memória comum do movimento e das igrejas e comunidades que foram se formando no transcorrer do tempo. Além das experiências vivenciadas diretamente com o Espírito Santo, nas formas do falar em línguas, do testemunho dos milagres e nos testemunhos eloquentes da fé, as mulheres pentecostais foram um tipo de reservatório da oralidade e da memória, transmitido pelas gerações, aos filhos, aos vizinhos e parentes evangelizados.

A maior evidência dessa dinâmica da memória foram, certamente, os chamados círculos de oração, que eram e ainda são, reuniões informais lideradas por mulheres que semanalmente agregam pessoas para as experiências coletivas de oração no espaço da casa (SANTOS, 2006, p. 54). Nelas, os elementos mais fundantes do pentecostalismo se reproduzem num espaço distinto do templo, onde a liturgia é conduzida pelo pastor como protagonista do sagrado. Em todo o Brasil, os círculos de oração formaram uma experiência de sociabilidade cotidiana muito significativa, onde o sobrenatural, o místico, o mágico ou a própria intervenção divina nos dramas humanos tornou-se algo ordinário e esperado pela crença comum da proximidade com esse sagrado. Em outras palavras, Deus e sua revelação simbolizados e concretizados pelo livro sagrado, a Bíblia, eram eventos iminentes nos acontecimentos do cotidiano, epifanias tornadas ordinárias.

Os círculos de oração funcionaram, entretanto, como espaços alternativos aos que eram controlados pelos homens, embora, não poucas vezes, tornaram-se concorrentes e ameaçadores ao poder masculino, geradores de tensões e de negociações. Eles foram um meio de empoderamento feminino numa estrutura eclesiástica que foi se tornando cada vez mais regida e controlada pelos homens, não menos verticalizada, mas que se deparavam com a emergência de lideranças femininas com seus carismas e autoridades oriundas das experiências, do discurso e da memória. Impedidas de serem ordenadas pastoras, as mulheres criaram seus próprios espaços de poder a partir da casa onde o proselitismo e as manifestações do sagrado aconteciam à parte do espaço oficial do templo. Esse empoderamento, evidentemente, se projetava para a vivência da comunidade criando lugares e discursos que não estavam diretamente subordinados ao pastor e aos dirigentes, criando tensões e conflitos.

Nas reuniões aconteciam os típicos elementos pentecostais como o falar em línguas, as profecias, as revelações, as intercessões e o compartilhamento 
de experiências de fé, de milagres e de mudanças de vida, como respostas das orações e demonstrações do poder de Deus. Conhecidas como "profetizas de cozinha" muitas dessas mulheres foram agentes determinantes para o crescimento da comunidade, na conversão de parentes e vizinhos, responsáveis pela formação de uma linguagem feminina própria e de uma memória que construiu sentidos para aquele segmento religioso. Porquanto, não somente as reuniões eram feitas para a coletividade, mas também atendimentos individuais mediados com palavras de orientação, exortações e profecias e adivinhações sobre o vir a ser dos dramas pessoais.

Lideranças antigas dos círculos de oração se tornaram reservas de memórias para a história do movimento pentecostal. A capacidade de conhecer e guardar pessoas e nomes, a influência dentro da comunidade e na estrutura eclesiástica, o reconhecimento de suas trajetórias pessoais na igreja, a percepção singular dos problemas e das mudanças ocorridas nessas estruturas e o saber de histórias, segredos e experiências, tornam essas mulheres com seus depoimentos um nicho fundamental para a memória pentecostal a partir da sua oralidade.

\section{Considerações Finais}

Atualmente, o movimento feminista encontrado no campo religioso, nos universos do sagrado e da espiritualidade, articula-se, dentre outros discursos, por meio da teologia feminista, que parte de outras interpretações da tradição e das escrituras desde o olhar e a condição das mulheres, pertencentes a diversas crenças religiosas. Alinha-se ao ecumenismo e ao diálogo inter-religioso como espaços de mobilização, de denúncia e de reafirmação da igualdade de gênero, deslocando os discursos religiosos e teológicos tradicionais das matrizes patriarcais da sociedade, para uma releitura dos direitos, da dignidade, da igualdade e de autoafirmação. Certamente, a experiência e a vivência das espiritualidades têm alterado a relação com uma divindade exclusivamente masculina.

As mulheres criaram e reinventaram formas de afirmação no espaço religioso, sendo protagonistas do fazer religioso (sacri facere). O sagrado foi, e ainda, é um dos espaços mais evidentes da resistência e do empoderamento feminino no cotidiano, com o domínio e o controle do simbólico pela via não do poder institucional, estabelecendo uma concorrência com os saberes oficiais (dogmas, vulgatas, sumas, confissões, tratados). A história das religiões em suas análises históricas e culturais centraliza essa perspectiva.

$\mathrm{Na}$ construção de uma memória religiosa oficial no âmbito das instituições controladas pelo poder masculino, os lugares e os papéis exercidos desde as formas de espiritualidades femininas, têm sido olvidados e secundarizados. 
Quando essa memória oficial se refere às mulheres ela lhes destina um lugar menor, ao mesmo tempo em que reforça o protagonismo dos sujeitos heroicizados.

\section{Referências}

AFONSO, J. A.; OLIVEIRA, I. B. de; STAMATTO, M. I. S.; SILVA, S. C. da. Educação e cultura protestante na transição do século XIX: circulação de impressos e diálogos luso-brasileiros. Revista Educação Pública. Cuiabá, v. 21, n. 47, p. 599-618, 2012.

ALENCAR, G. F. de. Matriz Pentecostal Brasileira: Assembleia de Deus 1911-2011. Rio de Janeiro: Novos Diálogos, 2013.

ANTONINO, M. E. Religião e feminismo, será? Nada é assim tão simples. Revista Educação Pública, Cuiabá, v. 21, n. 47, p. 599-618, set./dez.

2012. Disponível em: < https://medium.com/gg-feminista/religi $\%$ C3\%A3oe-feminismo-b09ae1474937>. Acesso em: 11 abril 2020.

BIDEGAIN, A. M. Gênero como Categoria de Análise na História das Religiões. In: BIDEGAIN, A. M. (org.) Mulheres: Autonomia e Controle Religioso na América latina. Petrópolis: Vozes/CEHILA, 1996.

CARDOSO, Douglas Nassif. Sarah Kalley: missionária pioneira na evangelização do Brasil. São Bernardo do Campo: Ed. do Autor, 2005.

Cotidiano feminino no segundo império. São Bernardo do Campo: Ed. do Autor, 2005.

DRESCHER, S. A sociedade civil e os caminhos para a abolição. História, São Paulo, v.34, n. 2, p. 29-58, 2015.

ELIADE, M. Tratado de história das religiões. Trad. Fernando Timaz e Natalia Nunes. 2. ed. São Paulo: Martins Fontes, 1998.

LIMA, S. I. O Protagonismo Feminino nos Primórdios do Protestantismo Brasileiro. Revista Científica Multidisciplinar Núcleo do Conhecimento. v. 02, p. 5-12, 2017.

MOTA, C. V. A missionária sueca perseguida no Brasil, internada em hospício e 'esquecida' pela História. In: BBC News Brasil, 2018. Disponível em:

$<$ https://www.bbc.com/portuguese/geral_44731827>. Acesso em: 7 set. 2019.

RAVERI, M. Índia e Extremo Oriente: a vida da libertação e da imortalidade. São Paulo: Hedra, 2005. 
ROSADO, M. J. O impacto do feminismo no estudo das religiões. Cadernos Pag, v. 16, p. 79-96, 2001.

SANTOS, L. de A. As outras faces do sagrado: Protestantismo e cultura na Primeira República Brasileira. São Luís: EDUFMA; São Paulo: Ed. ABHR, 2006.

SILVA, E. da. As mulheres protestantes: educação e sociabilidades. Revista

Brasileira de História das Religiões. ANPUH, n. 21, p. 161-190, 2015.

TAMAYO, J. J. Fundamentalismos y diálogo entre religiones. 2. ed. Madrid: Editorial Trotta, 2009.

ULRICH, C. B. A atuação e a participação das mulheres na reforma protestante do Século XVI. Estudos de Religião, v. 30, n. 2, p. 71-94.

VAUCHEZ, A. A espiritualidade na Idade Média ocidental (séculos VIII a XIII). Trad. Lucy Magalhães. Rio de Janeiro: Jorge Zahar Ed., 1995.

VERAS, L. A. C. S. Memórias da terra de Beulá: a construção de uma vida e produção de um lugar nas autobiografias de Eva Mills. 2017. .Dissertação O -, , 2017.

WEBER, M. A. K. R. O Movimento Mucker e suas relações com a igreja católica e a protestante. Revista Brasileira de História \& Ciências Sociais, v. 4, n. 8, 2012. 